\title{
for the Opening of the Picador Café: History - Myth - Literature
}

In autumn 1918, as Antoni Słonimski recollected years later, on the memorable day of the twenty-ninth of November when Warsaw was abuzz and crowds were rambling round the city in hectic excitement - those days when the words "freedom", "independence", "Poland", "communism", "revolution" did not have any shade of grey ordinariness or even disappointment or discouragement - we were full of enthusiasm, strength, and hope. The whole elite of Warsaw gathered on the evening when the Pikador Café was opened. That night the first roots of the literary tradition were put into the soil so as to grow into a tree of contemporary poetry. This soil did not lack fertilisation. The tree which grew had more blossom than fruit and, admittedly, some branches were bending to fall. With time the tree was turned into the tree of "News", but the bunch of flowers which matured dried forever in our books, has many beautiful and permanent scents.

During the first evening, Jan Lechon was reading his poem titled Mochnacki. A tall pale young man, in heavily worn-out jacket attire, reciting his poem in an emotional voice in a crowded café - this is one of more beautiful memories from those years of struggle and work ${ }^{2}$.

And here is the famous poem for the opening of 'Pikador': error.

1 The quotation, after A. Makowiecki, gives year 1818 - possibly a typographical

2 As cited in: A. Makowiecki, Warszawskie kawiarnie literackie, Warszawa 2013, pp. 81-82. 
Jan Lechoń

Mochnacki

Wr. 1832 Maurycy Mochnacki koncertowat w Metzu.

Mochnacki jak trup blady siadł przy klawikordzie

I z wolna jął próbować akord po akordzie.

Już ściany pełnej sali w żółtym toną blasku,

A tam w kącie kirasjer w wyzłacanym kasku,

A tu bliżej woń perfum, dam strojonych sznury,

A wyżej, na galerii - milcz serce! - mundury.

Tylko jeden krok mały od sali go dzieli,

Krok jeden przez wgłębienie dla miejskiej kapeli -

On wie, że okop hardy w tej przepaści rośnie,

Więc skrył się za okopem i zagra o wiośnie.

Rozpędził blade palce świergotem $\mathrm{w}$ wiolinie

I mały, smutny strumień spod ręki mu płynie.

Raz w raz rosa po białej pryska klawiaturze

I raz po raz w wiolinie kwitną polne róże.

Rosną. Większe, smutniejsze, pełniejsze czerwienia,

Coraz niżej i niżej, uschną, w bas się zmienią!

Nie. Równo, równo rosną w jakiś smutny taniec,

Rozdrganą klawiaturę przebłagał wygnaniec
Jan Lechoń

Mochnacki

Maurycy Mochnacki gave a concert in Metz in 1832.

Pale as a corpse Mochnacki sat at the clavichord

And very slowly began to play chord after chord.

Walls of the full hall already sink in yellow glow,

In the corner a cuirassier in golden helmet,

Nearer scent of perfume, strings of elegant ladies,

High on the gallery - be quiet heart! - uniforms.

There is just only one step between him and the hall,

One step through the hollow for the city orchestra -

He is aware the trench of this chasm keeps on growing,

So he hid behind the trench and will play about spring.

He made his pale fingers chirp in the treble

And a tiny miserable stream flows from his hand.

Time and again dew splashes on the white keyboard

And time after time wild roses bloom in the treble.

They grow. Larger, sadder and fuller with redness,

Lower and lower, they will dry, turn into bass!

No. Steady, steady they grow into some sad dance,

The expatriate somehow begged the trembling keyboard, 
I nagle się rozpłakał po klawiszach sztajer,

Aż poszedł szmer po sali, sali biedermeier.

Głupio, sennie, bezmyślnie kręci się i kręci.

Jakieś myśli chce straszne wyrzucić z pamięci,

Do piersi jakąś białą przytulił pierś drżącą

I czuje tuż przy piersi nieznośne gorąco,

I tysiąc świateł w oczach, w czyjejś twarzy dołki,

I zapach białej sukni, ubranej w fijołki.

Nagle złoty kirasjer poruszył się w kącie.

Sto myśli, jak kanonier, stanęło przy loncie,

Stu spojrzeń obcej sali przeszyły go miecze,

Wstyd idzie ku estradzie - czuje, jak go piecze.

Więc do basu ucieka i tępo weń tłucze,

Po tym tańcu szalonym niech ręce przepłucze,

Z tych czerwonych, duszących róż otrząsa płatki,

Rozsypuje po sali w tysiączne zagadki,

W sto znaków zapytania, sto szmerów niechęci,

Nie pyta. Już jest w basie. Już tam się wyświęci.

Raz, dwa, trzy, cztery - wali. Niechaj mu otworzą,

Niechaj wyjdą z chorągwią, wyjdą z Matką Bożą,

Niech mu końskie kopyta przelecą po twarzy

I niechaj go postawią gdziekolwiek na straży:

Na ulicy stać będzie z karabinem w dłoni...
And suddenly sztajer broke down on the keyboard,

Till murmur went across the hall in Biedermeier.

Silly, sleepily, thoughtlessly it spins round and round.

Wishing to erase terrible thoughts from memory,

He cuddled to his own chest some white trembling chest

And in his chest he already feels some horrid heat,

A hundred lights in the eyes, dimples in someone's face

And the sweet smell of a white frock, dressed in violets.

At once the golden cuirassier moved in the corner.

A hundred thoughts like a cannoneer stood at the fuse,

He was pierced by a hundred swords of the foreign hall,

Shame approaches the stage - he feels how it pricks him.

So he runs away to the bass and bangs it bluntly.

After this frantic dance let him rinse off his hands

He shakes off petals of those red stifling roses,

He spills them round the hall in a hundred of riddles,

In a hundred of question marks, murmurs of dislike,

He does not ask. He is at the bass. He will play there.

One, two, three, four - he bangs. Let them open him now,

Let them go out with the flag, with Mother of God,

Let horse hooves run quickly over his face

And let them place him in any place on guard:

He will stand in the street with a rifle in his hand...
173 
...Słyszy sala: ktoś idzie, ostrogami dzwoni -

Ostrogą spiął melodię, a akompaniament

Szaleje, krzyczy w basie, rośnie w straszny zamęt -

Ku sali bagnetami już mierzy, już blisko -

I ton jeden uparcie wybija

- nazwisko!!!

Wciąż czyste, w rozszalałe wplątuje się głosy

I wali, wali w basie murem Saragossy,

Oszalałych Hiszpanów wyciem, darciem, jękiem

I znów wraca ku górze załzawionym dźwiękiem -

W mazurze - nie - w mazurku idą wszystkie pary,

By całą klawiaturę owinąć w sztandary.

Zatrzymali się wszyscy w srebrzystych kontuszach,

A klawikord im ducha rozpłomienia w duszach

I wzdłuż długich szeregów przewija pas lity,

Tysiąc głów podgolonych podnosi w błękity

I wszystkie karabele jedną ujął dłonią, I uderzył w instrument tą piekielną bronią,

Aż struna się ugięła, ta w górze, płaczliwa.

I cisza jest w wiolinie. Cisza przeraźliwa.
...The hall hears: someone is coming, ringing with spurs -

He spurred the melody, and the accompaniment

Rages, shouts in bass, plays a terrible havoc -

Aims at the hall with bayonets, already near -

And stubbornly strikes only one tone - the name!!!

Still clear, it entangles in rampaging voices

And bangs, bangs in the bass with Saragossa's wall,

The distraught Spaniards with howling, tearing, groaning

And he comes back to the top with the tearful sound -

All the couples begin to dance mazurka.

So as to wrap tightly the keyboard in the flag.

They all stopped in silvery splitsleeve overcoats,

And the clavichord ignites a spirit in their souls

And along extended arrays wraps a solid belt,

A hundred of half-shaven heads rise into the blue

And he held all the karabelas in one hand,

And he struck the instrument with this hellish weapon,

Until the string bent, the one at the top, tearful.

And there is silence in the treble.

Dreadful silence.

Across the dead silly string, across the violet scent,

Across somebody's sad eyes, some white hand,

Across the lights of the night and whispers in the box, 
Po księżycu, po gwiazdach - mój

Boże! mój Boże! -

Gdzieś się gubi i zwija, przeciera pas

lity,

Po księżycu, po gwiazdach, po

Rzeczpospolitej.

Po sali idzie cisza przeraźliwa, blada

I obok tęgich boszów w pierwszym rzędzie siada.

Wzrok wlepia martwy, ślepy, w jakiś punkt na ścianie

I patrzy w Mochnackiego, kiedy grać przestanie.

A on, blady jak ściana, plącze, zrywa tony

I kolor spod klawiszy wypruwa

- czerwony,

Aż wreszcie wstał i z hukiem rzucił czarne wieko

I spojrzał - taką straszną, otwartą powieką,

Aż spazm ryknął, strach podły,

i z miejsc się porwali:

„Citoyens! Uciekać! Krew pachnie w tej sali!!!".
Across the moon, the stars - My God! My God! -

It gets lost somewhere and rolls up, wears through the belt,

Across the moon, the stars, the Polish Republic.

Terrible pale silence runs across the hall

And sits down in the first row next to stout Germans.

It sets its dead unseeing eye on some point on the wall

And looks at Mochnacki to see when he'll stop playing.

Pale as a wall he tangles and breaks the tones

And he extracts a colour - red - from the keys,

And finally he stood up and smashed the black lid

And looked with such a terrible open eyelid,

A spasm roared, mean fear, and off their places they rose:

"Citoyens! Run! There is a smell of blood in this hall!!!".

The dramatic, highly artistic work was declaimed by the author himself in a new literary café in Warsaw, opened only three weeks after Poland had regained independence. Commenting on Słonimski's memories on the circumstances of founding 'Pikador', Andrzej Makowiecki writes that after his return from Russia Tadeusz Raabe "spoke with enthusiasm about Moscow "cafés of poets»". He was particularly delighted with the café of futurists open from winter 1917 to April 1918 and managed by the artistic trio: Vladimir Mayakovsky, David Burliuk, and Wasilij Kamienski. Poetic texts were recited and musical pieces were played there (romances with the accompaniment of the guitar, etc.); artists were pulled onto stage and made to perform. As Makowiecki adds, "[the Moscow Café of Poets and the Picador Café in Warsaw] - both initiatives are a complete novum in the East of Europe and both put the European artistic revolution into practice ${ }^{3}$.

One may not fully agree with that last statement; similar places existed and enjoyed great success in Poland; perhaps not in an identical shape, but they were quite similar. Literary cafés were established as early as in the late

3 As cited in: A. Makowiecki, Warszawskie kawiarnie literackie, p. 84 [Unless indicated otherwise, quotations and titles in English were translated from Polish]. 
18th century in order for social and political life to be led, enriched with reflections on art. One hundred cafés were established in Warsaw at the beginning of the 19th century, including several of literary character. 'Kopciuszek' ('Cinderella') or famous 'Dziurka' ('A Small Hole') were frequented by poets, musicians, and painters - the broadly understood Bohema - but also by regular people. There was not always a separate 'stage', a place for performances or plays, but there were heated philosophical and literary disputes; poems and improvisations were recited; songs were sung; and even theatrical plays were performed. They were visited by Chopin, Norwid, Goszczyński, Zaleski, and, surely, the Mochnacki brothers. In the first part of the 19th century, these places underwent particular development; after the defeat of the January Uprising, i.e. after 1864, literary cafés declined for some time, but not for long. The grand "literary career of coffee and the café will coincide with modernism", which is proven not only by historical facts but also character types from novels by Wacław Berent or Stefan Żeromski.

In the new Warsaw café at 57 Nowy Świat Street, the poet who inaugurated the café with his declamation was barely nineteen; his colleagues - the future Skamander poets - were only slightly older. They had just opened a cultural café with a belligerent name in Poland liberated after years of enslavement: it is worth reminding the dictionary meaning of the word 'picador' (from Spanish - an active participant of the corrida, an assistant of the matador, whose task is to prick the bull and provoke it to attack). This 'prick' perhaps, toutes proportions gardées, was supposed to be the aim of young and uncompromising authors who at last 'were in their own house' and could, also at last, abandon the national liberation topic prevalent for years for the benefit of the free choice of areas of artistic expression. They could abandon the so-called 'Polish duties' and deal with what they wanted, also remaining in the sphere of 'potentiality' rather than 'necessity'.

And yet... The teenage poet inaugurates the activity of a cultural café intended to be opinion-forming with a poem whose topic and form are traditional; ardently patriotic, extolling "the Romantic tribune of insurrectional Warsaw" (as Maurycy Mochnacki was commonly referred to); with a poem in the stylistics that gives way to the 'new', stylistics typical of Romanticism and the Young Poland, with a multitude of epithets, emotional hyperboles, and a liking for synesthesia.

What was the reason for choosing such a text in a nominally satirical cabaret, whose famous ironic and grotesque Regulations assumed abolishing monuments rather than erecting them?

Indeed, when Słonimski presented his idea of establishing a café of poets in the literary section of the artistic club whose members were writers

${ }^{4}$ The historian of the phenomenon added: "The café gave an opportunity to talk both with a circle of friends as well as with a broader public, it fostered integration of different circles. It used to be a place of conspiracy meetings. Sometimes guitarists and singers gave performances there. It was a place where one could also compare opinions and judgments from newspapers or conversations on the current literary, theatrical, musical or political events". Importantly, the café also "catered for direct contact of authors with the public". Cf. R. Kanarek: 'kawiarnia literacka' [entry], in the volume: Stownik literatury polskiej XIX wieku, eds. J. Bachórz, A. Kowalczykowa, Wrocław 1991, pp. 405-407. 
who were "terrific and not very prolific", the survivors of the Young Poland, they mocked the idea of their younger colleague ${ }^{5}$. For traditionalists, it must have been too bold, too democratic (it assumed, for instance, the complete abolition of the line between creators and the audience), perhaps even too boorish. Fortunately, as Słonimski recalls, "slightly later the fate brought me together with a couple of «sensible blokes». I got to know Leszek Serafinowicz and Julian Tuwim. It was then that the triumvirate was established, this «dictatorship of poetariat» which we proclaimed to the public with our addresses." ${ }^{\prime \prime}$

One of such "addresses" was the 'Pikador' regulations created by the pure nonsense Słonimski-Tuwim ${ }^{7}$ duet that turned out to be longer lasting that the "triumvirate". The 'rules' of these comic Regulations and Price List for Guests included, for instance:

$\S 1$

It is not allowed to bring dogs.

$\S 2$

Entrance fee for adults - 5 German marks. School youth aged 16-20 - 10 DM.

Children aged 8-16 - 15 DM, children aged 4-8 - 25 DM. Children under 4 - 35 DM.

Each adult person has the right to bring any number of breastfed children

- with an extra charge of 50 DM per piece, regardless of the sex, confession and nationality.

§3

Haggling with the cashier about ticket prices is to no avail. We expect high additional charges. We refuse to accept any silly 10 or $15 \mathrm{DM}$ of additional charge. We'll do without!

[...].

It is then followed by an enumeration of seven more extremely extended points of Regulations, which include: retail presentation of more and more expensive poetic "services", such as: writing dedications at different price rates, or a handshake - also costing a small fortune; dates of accepting possible marriage proposals; and a list of unwanted guests which includes the unfortunate (and, luckily, non-existent) counsellor Józef Kuśmidrowicz, "a symbol of the pompous small-town aesthete"

The café-cabaret, where the regulations "forbade the guests to beat poets with chairs", did not let in persons who are "too sober" as well as they particularly strictly banned "guessing the rhymes during declamation of poems". The inauguration ceremony featured a poem which was solemnly patriotic, unambiguously serious, solemn, written in the language of

${ }^{5}$ As cited in: A. Makowiecki, Warszawskie kawiarnie literackie, p. 81.

6 Ibidem, p. 81.

7 Between 1920 and 1936, they wrote together many satirical poems to be published in the Warsaw-based Kurier Poranny. The works were characterised by typical British humour, which one can see for oneself when reading those gathered in the volume titled W oparach absurdu (In the Fumes of Absurd), published after the war (Warsaw 1958).

${ }^{8}$ As cited in: A. Makowiecki, Warszawskie kawiarnie literackie, pp. 92-93. 
Romantic emotionally omnipotent hyperbole, at times bordering on kitsch, and maybe even epigonic. Why?

It is difficult to provide one unambiguous answer.

It is probably the conviction about the fully understandable temporary surge in patriotic, social, and liberation feelings that made the poets choose such a 'topos for the inauguration'. 'Poland had existed' for several days, and on the 29th of November - the day of the opening of 'Pikador' - was the eightieth anniversary of 'the November night'. The memory of such events and heroes was still very vivid in the society, especially in the capital, and Maurycy Mochnacki - a writer, a pianist, an imprisoned revolutionist, and, finally, an emigrant - was a model hero of the nineteenth-century archive of Poles' memory. Controversies around his attitude to tsarist authorities, doubts concerning his decisions and choices, and some flaws on his portrait only confirm his Romantic split and tragic trait which impressed his compatriots.

The clash between the extremely solemn beginning and the satirical continuation of the 'Pod Pikadorem' café can be explained by literary scholars with the discrepancy between the assumptions of manifestos and their subsequent executive (writing) practice, which often occurs in the history of literary creative groups.

Hence Mochnacki by Lechon is not a rebellious or innovative poem on the level of poetics, stylistics, or versification. It is, nevertheless, 'revolutionary' in its ideological and emotional layer at the moment of the declamation; it is written with panache by "a precociously mature boy", brought up in a home full of historical memorabilia, books and tales concerning the insurrectional revolts of the 19th century. As Roman Loth writes, "His mother's tales on the history of Poland and his father's national radicalism directed the young poet towards Mochnacki"9.

Already in 1915, Leszek Serafinowicz wrote a one-act play titled W noc jesienna (At Autumn Night) about the role of Maury Mochnacki in the November Uprising. Fascinated by the figure of the Romantic writer and musician, three years later he made him the character of his poem.

There are many interpretations of Mochnacki depending on the time when they appeared, pointing to different aspects and ambiguous - and potentially possible - intentions of the author as well as ideas for the 'overtone' of the work. There is agreement concerning the thematic 'point of departure': introducing the protagonist's lyrical situation and the theatricalisation of this situation, poetic visualisation of the poet's dramatic performance.

Maurycy Mochnacki, a historical figure, becomes a literary character and, in an emotional poetic transformation, not so much a pianist giving a concert for the French audience as a tragic emigrant in a foreign land, who gives an account of the tragic history of struggle for Poland's independence through a piano interpretation.

9 R. Loth, Lechoń, Mochnacki, historia, "Rocznik Towarzystwa Literackiego im. Adama Mickiewicza" 1988, no. 23, pp. 26-27. 
Modelled on Mickiewicz's concert of Jankiel from the 12th book of Pan Tadeusz (Master Thaddeus) and, in all probability, also on Koncert Chopina (A Chopin Concert) by Artur Oppman, or Or-Ot, the poem is intended to be a description of an artistic event which was Mochnacki's performance in Metz. It may assumed that it is "thematized music", a poetic presentation of a musical concert, a poem of descriptive character; yet music is not often mentioned in the text itself.

This is rather a description of playing music: ravishing, passionate, even dangerous at times; an inspired artist who does not play notes, but improvises; he does not try to provide the listeners with pleasure, but he attacks, provokes, surprises, teases, and even terrifies them.

These extra-musical elements of the clavichord improvisation are assembled in a sequence which is internally disturbed. They manifest the conflict of the conscience of the artist: Mochnacki plays either against himself or against the audience. The motifs why he tries to win the audience - double foreign, French and bourgeois - playing about "spring", about love, a waltz making "the hall of Biedermeier" murmur with recognition - is perceived by him as a betrayal of his own ideals, ideals of life and struggle [...]. A sudden turn takes place: using battle and sacrificial motifs, national and historical as well as revolutionary motifs in music. But this very approach makes him lose contact with the audience, now not understanding anything, cold and unwilling ("Citoyens! Run!"). [...] The dramatic gesture of the virtuoso at the end of the work cuts through this series of misunderstandings - it is not until now that it becomes clear the most important motif of Mochnacki's improvisation was the revolution. The panic-stricken reaction of the middle-class auditorium mirrors a not very remote echo of the July of 1830 in Paris.

For the artist it was supposed to be the echo of the past November days $[\ldots]$

This way, Roman Loth, the poet's biographer, sums up his interpretation of the poem ${ }^{10}$.

For Mochnacki - a work of poetic imagination - the echo of November 1830; for Lechon himself - the near echo and glow of November 1918, the November of freedom, the month of liberation which had been awaited for so long.

Apparently, the young poet was extremely fixated on eminent figures from both the distant and current history of Poland. Thinking of justified thematic parallels, Loth compares Mochnacki by Lechon to other poems of the author, e.g. to Pitsudski, pointing to similar features of the author's imagination and his literary decisions. 
Lechon "ostentatiously ignores the generally accepted facts from public life", "bends the historical truth to his vision and ideas", builds a myth distanced from the reality and makes an apotheosis of his heroes. Mochnacki and Pitsudski close the volume from 1920, titled Karmazynowy poemat (A Crimson Poem); it opens with the famous Herostrates (Herostratus) and Duch na seansie (A Ghost on a Séance) (about protagonists whose activities have a negative impact).

As the researcher writes, "Pitsudski is a glorification of the eponymous protagonist of the poem, Mochnacki - is a glorification of the idea of Piłsudski, armed struggle for independence "despite everything»".

"Lechon sees in Mochnacki an apostle of the Romantic deed whose idea was covered by the ash of failure and despair in the consciousness of the nation, died under the burden of messianic concepts and martyrlogical brooding and which needed to be revived"11.

The "conceptual programme" of Mochnacki can be explained in terms of an enthusiastic support of Lechon himself and the circle of his friends for the attitude and current policy of the Marshal; Lechon considered both the Romantic pianist and the Marshal contemporary to him - the co-creator of Polish independence - to be "patrons of Romantic realism", which he continued to express long after Poland had regained independence and during the years of the war exile.

This is why the poet depicted the concert in Metz with such ardour and enthusiasm; why he did not spare pathos, paleness, roses, and redness of blood in it. The exaltation of the poem was his own exaltation, the emotion of the pianist and improviser was his own emotion.

"In reality, the course of events looked different". As the historian of poetry and Lechon's works argues:

Involved in hopeless political disputes of Paris emigration, writing frantically at the time the history of Powstanie narodu polskiego, at the beginning of January 1832 Mochnacki left for Metz, where a cordial friend of his, Michał Podczaszyński, was staying. He lingered there for nearly three months. He had a busy social life there, winning immense popularity. He went to great lengths to write his work. On 20 January 1832 Podczaszyński wrote to Marycy's mother, to Galicia:

"Nobody in whole Metz plays the piano like him. He gets applause everywhere. - Ladies have already made a project for him. They want him to give a concert for the poor".

The concert, in which Mochnacki's performance was only one of the points on the agenda, took place on 23 March 1832 in the hall of Société Philharmonique. Mochnacki played, accompanied by the orchestra, a concert

11 Ibid., p. 33. 
of Johann Nepomuk Hummel, achieving great success. Podczaszyński described both preparations for the concert and the concert itself to Mochnacki's parents in great detail and in a humorous manner. It is worth quoting this description $[\ldots]$ :

The day of the concert came. Maurycy had to choose a piano for himself, many ladies proposed to him with their instruments [...] and Maurycy had plenty of pianos to choose from but he was hesitating between only two of them, and the worst ones, as one belonged to Mrs B., and the other to Miss Klementyna S. The first one was incomparably better, all amateurs agreed with that, it was even brought to the theatre, but after hesitating for a long time Maurycy decided to send it back, and gave priority to Miss Klementyna's piano! Mr Solleral, the old major of sappers, a great eccentric, a man who learns politics from Monitor, conducted the orchestra. During the rehearsals when there was no instrument, he sang solo through the nose in his hoarse voice. Eventually, he waved his hands so much, he turned so much that the following day he got a cramp, his right hand trembled, his legs hurt, he had a headache, fever and indigestion. We thought that it was cholera morbus. A concert of symphonies, choirs, overtures began [...]. After singing, after the symphonies, after solos on the harp and clarinet Mr Solleral led our culprit onto stage. Thousands of applauses, thousands of opera glasses shone from everywhere in bright light, they greeted him with thousands of screams, and there were as many perspectives as there were loges. There was far more fear for Maurycy as compared to Grochów or Ostrołęka. But he did not get scared and played the Hummel concert. And he put on such elegant attire that you would hardly recognise him. [...] It came as no surprise that he played wonderfully, that he was greatly applauded after each solo, after each passage. He did everything well. Standing behind him, Mister Solleral almost hit the piano with his nose on a few occasions as he bent and turned so much, and he even once bounced Maurice in the head, drumming the beat in musical zeal, but luckily it passed rather unnoticed. Maurycy was the king of the day in Metz on 23 March; people did not talk about anyone else but him ${ }^{12}$.

While reading Podczaszyński's letter, the following thought comes to mind: the description of the concert by Mochnacki, an elegant artist adored by ladies, playing for charity under the baton of a crazy conductor-amateur who smashes the soloist with the bow on the head because he conducts his orchestra so passionately - this concert, its description, seems far more appropriate as a 'piece' for the opening of a modern, cabaret stage of poets than Lechon's mythicised "apotheosis of Romantic struggles for independence", adorned with the Romantic "corpse paleness" of the soloist; than "Lechońs voice on contemporary times" dressed in historical attire (Loth). A voice, which eventually inaugurated the activity of 'Pikador'.

12 Ibid., pp. 27-28. 
But a story is a story, literature is literature, and a myth is a myth. Lechon showed here his complete désinteressement for facts, and he was also the furthest from wishing to repeat the humorous tone of the private letter-testimony in his poem. He needed pathos to convey the lofty version of events inspired by the 'national spirit'.

Questions concerning the convergence or discrepancy of the historical and poetic accounts would not have been raised, since the poet has no duty to render a detailed description of past events in his poetry. In contrast, the consecrated right to his own vision and even creation of events 'based on' history has been obvious for both creators and recipients of literature since Homer's times. It was not in vein that Goethe placed his literary output between 'truth' and 'invention', writing of the inspiring Wahrheit and necessary Dichtung. The problem is that Lechon's poem is accompanied at its very beginning by one modest informative statement, namely that "[in] 1832 Maurycy Mochnacki gave a concert in Metz", suggesting a strong relationship between Dichtung and Wahrheit, whereas the poem titled Mochnacki takes place somewhere between Dichtung and... Dichtung.

In his Dziennik (Diary), Lechon mentions on a number of occasions that the last two poems of Karmazynowy poemat were written in a state of nerves, in a bad mental condition, among obsessions taking control of him:

I was writing then with despair and in despair, having written Mochnacki and Pitsudski I felt despair, some kind of disaster, I subscribed to hopeless sadness, I did not exist then - there was only the trembling medium, writing under a dictatorship of some secret, oppressive powers ${ }^{13}$.

The "trembling medium" through which a stream of poetry emanates with verses of the highest emotional intensity. Interpreters of the poem agree that the melody of the poem grips and fascinates the recipient every time similarly to how it could have gripped and fascinated the audience of the premiere as recited by Lechon himself in the 'Pod Pikadorem' café on that memorable November day of 1918.

The poet "will lead the audience where he wishes", as Jerzy Kwiatkowski argued, adding rhetorically: "Who will resist the scream of terror of the bourgeois in Metz"14? Ireneusz Opacki, in turn, complemented the external profile of the emotional impact of Lechon's poem with in-depth comments on the lyrical situation; according to him, the protagonist of the poem, the performer of the historical concert, Maurycy Mochnacki, is not (was not in the poetic vision) capable of gaining control over the hall; he is unable to seduce the audience with his zealous performance and passionate interpretation:

[...] it is not Mochnacki that takes control of the hall but it is the hall that takes control over Mochnacki. It is not the audience that reacts to the

13 Ibid., p. 34.

14 J. Kwiatkowski, Szkice do portretów, Warszawa 1960, p. 16, 45. 
concert but it is the pianist that reacts to the stimuli from the audience, its gestures, its looks, and the character of the concert changes under their influence ${ }^{15}$.

Barbara Czarnecka, who analyses the literary output of Lechon with regard to his suppressed sexual orientation, sees in Mochnacki an expression of his artistic sublimation:

The source of sublimation is inexpressibility [...] In literature sublimation is not projected, it is not dictated by the tactics of simple change. To be in the role of the artist who 'sublimes' means to often seduce - as if 'instead' - only with what may be revealed, but to express at the same time the whole scale of passion. In Karmazynowy poemat we get to know the sublimation which is manifested through patriotic passion, observing Mochnacki play ${ }^{16}$.

And later:

Passion is manifested despite the will of the artist. It is manifested through hyperbolic, trans performance: its intensity of imaging, maximalism of scenes, ecstasy. [...] The response is 'appalling silence' which is contained on the part of the recipient. It expresses foreignness and cultural disapproval, it is a dead anticipation of silence, of the moment when the voice of passion dies down ${ }^{17}$.

Hence the poem about Mochnacki's concert would be an 'involuntary confession' and a tale on 'the torment of keeping silence'. In accordance with this approach, Lechon would include his spiritual struggle concerning his sexual orientation in the 'homo-text' or, in reality, in homo-texts, since also other works referring to national martyrology and its heroes were to speak about his concealed yet real nature. By contrast, the entire Karmazynowy poemat would constitute a certain 'seductive sublimation', which already manifested in the magnetic recitation during the opening of the 'Pod Pikadorem' café ${ }^{18}$.

Mochnacki by Lechon has several vivid artistic features which warrant the author's literary immortality. They include:

- prominently shaped rhetoric which ensured the author's first stage success $^{19}$;

- the theatricalisation of the lyrical situation ("Lechon's theatre was fascinating and impressive but [...] a smell of old decorations hovered over the stage of his poems ${ }^{\prime 20}$ ), often giving it an anachronic dimension;

${ }^{15}$ J. Opacki, Wokót 'Karmazynowego Poematu' Jana Lechonia, "Pamiętnik Literacki" 1966, vol. 4 , p. 481.

16 B. Czarnecka, Ruchomy na szali wagi. Lechoń homotekstualny, Toruń 2013, p. 71.

17 Ibid.

18 "Lechoń gained popularity straight away", as Roman Loth noted in his introduction to the edition of Lechń's poetry, op. cit., p. LXXXVI.

${ }_{19}$ J. Kisielowa, Retoryczność i melancholia. O poezji Jana Lechonia, Katowice 2001.

${ }^{20}$ M. Wyka, Szkice z epoki powinności, Kraków 1992, p. 91. 
- blind admiration for Romantic models and even adding hyperboles to them ("Someone who will read Karmazynowy poemat by Lechon for the first time may be somewhat disappointed: they were opening the book with a conviction that they would deal with someone «young», the so-called «futurist» - they come across topics so fusty, tones heard so long ago that despite will they start looking for the year of publication"21);

- a specific historiosophic approach to the selected fragment of Polish history of a universal character;

- ardent patriotism ("Each poem of Karmazynowy poemat awakes Poland in the psyche of the reader, enriches him with emotional substance which can be shaped according to the individual model of patriotism. Lechon understood in this way always increases the temperature of this feeling" ${ }^{22}$ ).

To sum up:

it is possible to say that Lechon sensed, recognised the 'collective energy' very accurately, he knew how to be popular, he had a strong emotional impact, he became unique although he also caused controversy in the sphere of intellectualisation of this impact. His work evoked admiration and the feeling of dealing with a genius, on the one hand, and an intellectual dissonance, on the other ${ }^{23}$.

Lechoń was interested only in "emotions of great intensity", as well as "monumentalising history, celebrating Polishness, heroism of characters and dramatism of events"24. Mochnacki is an excellent example of this and a proof of the real talent of the poet; a poet important in the literary life created anew in Reborn Poland, but was he a modern poet?...

A new chapter in the history of literature was just beginning. Many years later, Słonimski would confirm the strength of the impact of young poetry on recipients. "We introduced to poems", as he writes with pride, "the concreteness of imagery, power and truth of the word [...]"; We we're capable of sparking enthusiasm for poetry in this street café", and "each new poem became an event at that time" 25 .

Who knows whether this is not the greatest historical merit of Lechon's poem for Polish literature. In the combination already described many a time, and one that is perhaps non-describable - that of history, myth, and poetry - "the divine element" of these works remained, namely emotions. Emotions which were thought over by the poet and felt by that audience from 'Pikador'. Due to different historical conditionings, it is impossible today to describe and reconstruct them. Or it is possible for another poem, which after years revived the atmosphere of the first literary café in the free Poland:

${ }^{21}$ In the review of Wilam Horzyc, cf.: Dzieje Konrada, Warszawa 1935, p. 115.

${ }^{22}$ Cf. J. Opacki, Wokót 'Karmazynowego Poematu' Jana Lechonia, "Pamiętnik Literacki" 1966, vol. 4, p. 481.

${ }^{23}$ Cf. J. Kwiatkowski, Czerwone i czarne. O poezji Jana Lechonia, "Życie Literackie" 1956, no. 39 , p. 5.

${ }^{24}$ B. Czarnecka, op. cit., p. 80.

${ }^{25}$ As cited in: A. Makowiecki, Warszawskie kawiarnie literackie, p. 82. 
Na krakowskim w kawiarni zadymionej sali,

Na estradzie niewielkiej, codziennie wieczorem

Jacyś młodzi poeci wiersze swe czytali

I uciszał się nagle tłum „Pod Pikadorem".

I szumiały Muz skrzydła w małej kawiarence,

Gdy Lechoń kartkę z wierszem w drżącej trzymał ręce...
In Krakowskie Przemieście in the smoky room

Of the café on a small stage, every evening

Some young poets recited aloud their poems

And suddenly the crowd in "Pikador" died down.

And the wings of Muses whirred in the small café,

When Lechon kept his poem in his shaking hand...

The piece of paper with the poem on it is still shaking, not making it easy to read the author's handwriting completely and unambiguously. The questions about the shape of Mochnacki and the secret of inaugurating with this poem a Warsaw literary cabaret one hundred years ago will probably remain unanswered.

\section{REFERENCES}

Czarnecka B., Ruchomy na szali wagi. Lechoń homotekstualny, Toruń 2013.

Horzyca W., Dzieje Konrada, Warszawa 1935.

Kanarek R., Kawiarnia literacka, [in:] Stownik literatury polskiej XIX wieku, eds. J. Bachórza, A. Kowalczykowej, Wrocław 1991, pp. 405-407.

Kisielowa J., Retoryczność i melancholia. O poezji Jana Lechonia, Katowice 2001.

Kwiatkowski J., Czerwone i czarne. O poezji Jana Lechonia, "Życie Literackie" 1956, no. 39 , p. 5 .

Kwiatkowski J., Szkice do portretów, Warszawa 1960.

Loth R., Lechon, Mochnacki, historia, "Rocznik Towarzystwa Literackiego im. Adama Mickiewicza" 1988, no. 23.

Makowiecki A., Warszawskie kawiarnie literackie, Warszawa 2013.

Opacki I., Wokót 'Karmazynowego poematu' Jana Lechonia, "Pamiętnik Literacki" 1966, vol. 4.

Wyka M., Szkice z epoki powinności. Kraków 1992.

\section{SUMMARY}

The founders of the first literary café in reborn Poland, namely 'Pikador' in Warsaw, chose a poem by Jan Lechon for the inauguration ceremony in November 1918. In the poem, titled Mochnacki, the young poet recollects a historical concert of Maurycy Mochnacki, a Romantic tribune of the 19th-century Warsaw, a pianist and a writer. Different possibilities of interpretation of the work, which is heavily emotional 
- ranging from patriotic poetry, through an almost social satire to an intimate confession encoded in the form of a description of a piano concert and reactions of the foreign audience to it - are not contradictory as they complement each other well.

\section{Keywords}

Romanticism, Reborn Poland, literary café, patriotic poetry, independence poetry

Joanna Maleszyńska - works in the Department of Poetics and Literary Criticism in the Institute of Polish Philology at Adam Mickiewicz University in Poznan. Her research interests include iterary and musical forms represented by different genres, opera, and musical, but also hymn and song as well as librettology, the history of old and 20th-century lyrical poetry, the cabaret of the interwar period, the war and occupation, specificity of popular culture, and European tradition in the Polish literature. She is the author of the book titled Apologia piosenki. Studia z historii gatunku, Poznan 2013. e-mail: jwmalesz@amu.edu.pl 